\title{
Archival automation in the United Kingdom and the relationship between standardization and computerization
}

\begin{abstract}
:
Continuing in a tradition of looking back at the history of the archival profession's engagement with and response to computers, a story is told of early archival computerization and the development of standards in the UK from the mid-1960s to roughly the mid-1980s. Standardization and computerization initially emerged as separate threads, but these threads started to coalesce in the mid-1970s and soon became intertwined in a project of systematization, driven by a need to balance the competing pressures to both specify and generalize. This project of systematization however, took as its focus the creation of finding aids and the standardization of data input necessary for that purpose. As such archivists placed themselves on the outside of another project of systematization going on at the same time; that of the systematization of computers as information storage, manipulation and retrieval systems. In the UK, beyond perhaps a brief moment in the mid to late 1960s, archivists did not engage with the development of the conceptual (general) principles of the new information technology or with the ways in which meaning was being structured, represented and manipulated inside these new 'machines'. This raises a question about the level and terms of the archival profession's engagement with computers and suggests that greater awareness of the terms of engagement, both in the past and the present, would be of benefit to the future success of that engagement.
\end{abstract}

Keywords: Archival description: Automation: Data standards 


\section{Introduction}

Interest in looking back at the archival profession's engagement with computers has been long-standing, but sporadic. ${ }^{1}$ For example, as early as 1984, Thomas Elton Brown's retrospective characterized the Society of American Archivists' (SAA) response to the computer as antagonistic and confrontational. ${ }^{2}$ More than twenty years later, Betsey Baldwin also characterized early efforts at the Public Archives of Canada to engage with the computer as adversarial. ${ }^{3}$ The purpose of both these articles in looking backwards is not made explicit, although Baldwin does state that the thinking of those archivists who encountered early computers is still relevant today and that 'the discourse of this original decade of computer use serves to remind us of the foundational intellectual debates pertaining to technological change and archives' ${ }^{4}$ A similar argument is made more forcibly by Greg Bak in his recent (2016) two-part consideration of writings on digital archiving in Canada. Bak characterizes the ideas and approaches of the early computer (or as he terms it the MRA machine-readable archives) era as 'knowledge gradually won, carelessly lost, and painfully recovered', which is now proving fundamental to contemporary archival practice. ${ }^{5}$ There would seem to be a general sense then, that it is beneficial to look back and learn from the past, that, as Bak puts it 'As we continue to grapple with the multiple challenges posed by digital archives, we would do well to look to our own history' ${ }^{6}$

This article will continue in a similar vein, but it will present an original perspective in a number of ways. Firstly, it will situate itself in the context of the United Kingdom (UK), rather than the North American one dealt with in the literature mentioned above. This distinction is particularly important for a number of reasons. Firstly, in the broader context of the history of computing, at least in the period from the end of the Second World War until the late twentieth century, the computing landscape in the UK was more distinct from that in North America than it is today. For example, whereas the early North American market was dominated by IBM in conjunction with what became known as the BUNCH (Burroughs, UNIVAC, NCR, Control Data and Honeywell), in the UK a host of different companies were operating, eventually being merged together in 1968 to form International Computers Limited (ICL). ${ }^{7}$ Indeed ICL was deliberately set up to maintain a separate British computer industry that could compete with the leading players, such as IBM. ${ }^{8}$

Secondly, the specifically UK perspective is important because the UK archival profession's engagement with computers has developed along different lines from professional engagement in North America. For example, UK archival institutions have 
tended, at least until very recently, to purchase commercially-developed computer systems such as CALM and Adlib. ${ }^{9}$ In North America, or at least the United States of America, the picture has been different, with more community engagement in open source projects which have developed systems such as Archivist's Toolkit, Archon and their combined successor, ArchivesSpace. If we are to be able to understand the nuances of these differences, to compare them and learn from they reveal, we first need to separate the UK and North American contexts and to tell their stories of engagement with computers individually.

A second way in which this article will present an original perspective is that the learning it wishes to extract from looking back at the past is targeted towards a specific, rather than a general goal. This goal is to enable a more nuanced understanding of the relationships between standardization and computerization. In pursuing this goal, the article suggests that these relationships may be usefully viewed through a lens of systematization; to systematize something being to 'arrange [it] according to a system; to make [it] systematic; to devise a system' for it. ${ }^{10}$ In order to unpick these relationships, the processes of standardization and computerization will be considered both separately, in the first half of the article, and together, in the second. These two halves combined will tell the story of how these processes intertwined in the UK in the period from the mid-1960s to the mid-1980s.

Alongside the computerization literature referenced earlier, there is also a considerable body of literature dealing with archival standardization. ${ }^{11}$ Much of this literature dates from the 1990s - when ideas about standardization had a particularly high profile within the archival community - and later. This article seeks to look into the pre-history of this phenomenon. Increasing our understanding of the relationships between computerization, standardization and systematization, will also increase the potential for successful outcomes to the community's ongoing engagement with computers. The nature of this ongoing engagement can be seen, for example, in the recent development by the International Council on Archives (ICA) of the document Records in Contexts which responds to the emergence of new Linked Data technologies. ${ }^{12}$ Initiatives of this kind will be undertaken more successfully if they are carried out with an awareness that part of what lay at the heart of the community's earlier engagement was the ongoing negotiation of competing pressures to both generalize and specify, and above all, to systematize.

\section{The first decade: mid-1960s to mid-1970s}


Starting in the mid-1960s, standardization and computerization were initially the distinct, but not exclusive, foci of two separate groups within the UK Society of Archivists; namely the Subject Indexing Working Party and the Computer Applications Committee. These two foci started to coalesce in the mid-1970s on efforts to develop standards for that area of practice in which archivists felt the computer offered the greatest potential for transformation.

The Society of Archivists' Subject Indexing Working Party was active from 1967 to the mid-1970s. It sought to develop a scheme that would be comparable to the classification schemes used in libraries, but with more emphasis on the specific needs of archival institutions. ${ }^{13}$ It acknowledged that 'a system capable of being used with computers was highly desirable', but did not pay much attention to that aspect and did not have computerization as its focus. ${ }^{14}$ The members of the Working Party, looking back in the mid1970s, saw the main motivations for the setting up of the group in 'the growing need felt by many record offices in the 1960's for some finding aids to the growing numbers of catalogues.' Also, to a desire, attributed to Hugh Taylor, County Archivist at Northumberland, 'to find a reasonably quick way of processing the vast bulk of modern records so that subject information could be readily extracted from them'. ${ }^{15}$ From these beginnings, a group of interested archivists and librarians in the North of England came together to take discussions further. It met from 1963 to 1966 when it referred the matter to the Council of the Society of Archivists, which took it on and established its own Subject Indexing Working Party in $1967 .{ }^{16}$

The main motivating factor behind this attempt at standardization appears to have been a desire and a need to improve subject access to archival material. The wisdom of the time, at least as it was inherited from the experience of the library profession, was that whether or not computers were involved, this goal could be facilitated by using a standardized or controlled vocabulary. Despite this firm focus on the development of such a standard, there was awareness amongst some of those involved in the very early stages, notably Hugh Taylor, that the computer had potential for helping with the problem, and that it might offer a quick way of processing modern records. Taylor had sought to include Nigel Cox of the Newcastle University Computing Laboratory within the discussions and in 1964 Cox presented a paper on 'The computer as an aid to archive administration and historical research' at the Conference of the Society of Archivists. This led to 'happy visions of indexes being compiled and sorted by machine'. ${ }^{17}$ At the Society's Annual General Meeting also in 1964, Taylor contributed to a discussion about 'Automation and Archives' with reports of the 
discussions that had been taking place in the North of England. He offered the opinion that 'We must devise a scheme for subject indexing, and tackle the question of technical terms to make sure that archivists all used the same language'. ${ }^{18}$ The UK Public Record Office also entered into discussions with the Newcastle University Computing Laboratory in 1964 and a number of automated indexing experiments were conducted in collaboration between these two institutions throughout the rest of the 1960s. ${ }^{19}$

In contrast to the Subject Indexing Working Party's focus on standardization and the development of a standard subject indexing scheme or controlled vocabulary, the Computer Applications Committee of the Society of Archivists was focussed very much on computerization. The Committee was established by the Council of the Society of Archivists in 1973 at the instigation of the South East Region of the Society and their proposal was introduced and championed by Carl Newton, the County Archivist of East Sussex. ${ }^{20}$ Newton's interest in computer applications had already borne fruit at East Sussex Record Office, where he had initiated the automated cataloguing and indexing of archival material in 1970/71. ${ }^{21}$ With this action East Sussex became regarded as, 'the first non-national record office [in the UK] to undertake major automation. ${ }^{22}$ Evidence of this regard, and of the importance of the work of East Sussex Record Office comes from the fact that a meeting of what became known as the Committee on Automation of the International Council on Archives (ICA) (which had first met in Spoleto, Italy in 1972) was hosted in the county in $1974 .^{23}$ Both the ICA Committee and the Computer Applications Committee can be seen as arising from a desire for cooperation and collaborative effort within existing national and international professional frameworks to build a consensus about how to best deal with the implications of computing technology for all aspects of archival practice. ${ }^{24}$ As such, much of the work of these committees involved setting up training courses, newsletters and networks to pool and share experience and expertise in the area. ${ }^{25}$ There was much overlap in the membership of these committees. With the odd exception such as East Sussex Record Office, the vast majority of the work in computerization at this time was being undertaken by national institutions, such as the Public Record Office in the UK. It was therefore representatives from those national institutions who formed much of the membership of the international, and leadership of the national, professional committees charged with charting a professional response to these developments.

In the spirit of collaborative effort, the Computer Applications Committee issued a consultation document in 1974. In this document they expressed an interest in standardization in relation to both the best format in which to keep computer records, and also in the context 
that; 'It would undoubtedly help if as a profession we could achieve some measure of agreement on a standard terminology and on a standard style and format for our finding aids' ${ }^{26}$ Of these two areas however, it was very much around the second that the threads of standardization and computerization started to coalesce. The question of how to preserve and maintain computer (or born digital) records was therefore to a degree deferred, at least in terms of being the focus of immediate, concerted and community-wide standardization efforts. $^{27}$

As well as the consultation document, for wider circulation, the Computer Applications Committee also produced a report for the Council of the Society of Archivists. In this document, from 1975, standards were once again raised as an issue and one of the recommendations made was that 'standards in those areas of archival work which affect computer applications should be drawn up' ${ }^{28}$ The committee had already surveyed the areas in which computers were starting to make, or had the potential to make, an impact on archival work. These included management information applications, such as the statistical analysis of document use and the control of semi-current material held in records centres. The committee felt that applications in these areas were both 'less spectacular' and 'less complex'. ${ }^{29}$ In this view they may have been influenced, for example, by the fact that in the mid-1970s, East Sussex Record Office had redirected its efforts from the automated indexing and cataloguing of archival material, towards the simpler task of dealing with the control of modern records as part of its nascent records management function. The thought being that 'by virtue of its [the more modern records] being composed of a number of easily recognisable groups, each of standard format, computerized listing and indexing would be a much easier proposition than it had proved on the historical side'. ${ }^{30}$ Whilst not ignoring the simpler applications altogether, the committee do appear to have been much more interested in the computer's potential for 'information retrieval, either by automatic indexing, or, even more ambitiously, by interrogation of a computer-held data base'. ${ }^{31}$

This was the area which archivists, according to the Computer Applications Committee, found the most attractive, and in the early days of the Public Record Office's indexing experiments with the Newcastle University Computing Laboratory, a tiny number of them did directly engage with it. For example, Duncan Chalmers, in his report on some of the PRO's early experiments, talks of evaluating KWIC (Key Word in Context) and KWOC (Key Word out of Context) forms of indexing, as well as of engagement with PRECIS, developed by Derek Austin, a member of the Classification Research Group. ${ }^{32}$ As the Computer Applications Committee put it though, as archivists did become involved in these 
experiments 'the more experience they acquired, the more they became aware of the extent of the problems (not all of them technical) to be overcome. ${ }^{33}$ As a result perhaps, they started to engage with the computer less as an information (storage and retrieval) technology in itself and more as a tool that could be used in producing the sorts of finding aids (guides, indexes, lists) with which they were already familiar. For example, in 1969 the Public Record Office had started development, alongside its indexing experiments, of the PROSPEC system, which supported the production of various finding aids, including a guide to the Office's holdings, location lists and so on. ${ }^{34}$ The system was fully implemented by the mid-1970s and it was around this system that the Computer Applications Committee sought to develop the computerization of archival practice in the second half of the 1970s. It did so through the PROSPEC-SA (where SA stood for the Society of Archivists) project. This project involved ten other archival institutions using the computing facilities and PROSPEC system developed by the Public Record Office and will be discussed in more detail below. ${ }^{35}$ At the end of the first decade of UK archivists' engagement with computers, those 'happy visions of indexes being compiled and sorted by machine' were not going away. ${ }^{36}$ Through the work of the Subject Indexing Working Party and the Computer Applications Committee, the two, initially separate threads of standardization and computerization were starting to coalesce around that area of practice in which archivists felt the computer offered the greatest potential for transformation. Having briefly engaged with some of the more technical and conceptual underpinnings of the computerization of information and its subsequent retrieval, archivists soon shifted their attention to seeing the computer as just another tool. A tool that, like the index card, could support them in the processes of information storage, sorting and (re)ordering that had always been a vital part of their practice of producing finding aids. ${ }^{37} \mathrm{In}$ this way their engagement with standardization in the context of computerization took the form of a perceived need to 'achieve some measure of agreement on a standard terminology and on a standard style and format for our finding aids' ${ }^{38}$

\section{The second decade: mid-1970s to mid-1980s}

During this decade, standardization and computerization came together within the nested contexts of the production of archival finding aids, the PROSPEC-SA project and the work of the Methods of Listing Working Party which was affiliated to the Specialist Repositories Group of the Society of Archivists from the late 1970s to 1985. Coming together 
in this way, computerization and standardization coalesced around the perception and then the fulfilment of a need for standard terminologies, formats and styles of finding aids. In these efforts competing pressures were felt to both generalize and specify.

As was mentioned above, the UK Computer Applications Committee was very interested in taking forward a project to allow other archival institutions to use and benefit from the PROSPEC system developed by the Public Record Office. It favoured a cooperative approach as a way of reducing costs and making the most of the limited expertise that was available. ${ }^{39}$ Initially however this suggestion met with a disappointing response as detailed in a description of the setting up of the project, which appeared in the bulletin of the International Council on Archives' Committee on Automation in $1977 .{ }^{40}$ In reporting the steps taken to recruit participants, the report notes that the main point at issue in the discussions with potential participants was;

difficulties in seeing how PROSPEC might apply to their own record offices not, as might be expected, because they were anti-computer or unfamiliar with computer technology, but because their practices and archival terminology differed in some respects from those of the PRO. For example, there was a long discussion of what would constitute an entry or unit of description (the computer 'record'): in the PRO it is a 'class', but elsewhere it might be an 'accession' or a 'collection' or even a discrete part of a collection. ${ }^{41}$

The problem seemed to be one of not being able to translate well enough either between the individual institutional partners, with their disparate use of terms such as 'class', 'accession', 'collection', etc., or between the partners and the world of computer technology, with its terms of an 'entry', 'unit of description', and computer 'record'. The systems (in the sense of sets of principles, schemes, methods) used by the individual partners and the computer were not the same.

Problems of translation were further explicated in a paper prepared for the ICA Committee on Automation, which was published in 1978. Written by Arie Arad, from Israel, and Lionel Bell, from the UK Public Record Office, the paper highlighted some of the competing pressures mentioned above. ${ }^{42}$ On the one hand the authors of the paper noted that there was a pressure towards strict specification, for, as they put it, 'There is a need to define rigorously the elements and manipulations to be used since the computer's processes do not amount to the use of intelligence - they are themselves rigorous and predetermined'. ${ }^{43}$ On the 
other hand, working in the spirit of international co-operation, they also felt a pressure that 'definition has to be generalized to cover all archives institutions'. As they pointed out this made the problem much worse, as 'the archivist now has to make two jumps, the first to the analytical rigorousness demanded in any computer application, and again to the level of generality which will encompass all possible systems'. ${ }^{44}$

The PROSPEC-SA project did eventually get off the ground, supported by funding in the form of a British Library Research and Development grant. It took place between 1977 and 1978 and the participating institutions completed data sheets, which were checked by a general editor and then keypunched and processed, mostly by Peter Peregrinus Ltd, who also produced the output. That those involved felt the pressure for definition to be generalized to cover all (or at least ten) archives institutions has already been established, but the detailed guidelines produced for the participants also testify to the pressure for strict specification. Even so, difficulties were still encountered as the result of inconsistent means of constructing local reference codes and subject index terms.

Although the Public Record Office was the prime mover in early UK archival computerization, through its development of PROSPEC and leadership of the PROSPEC-SA project, it was not alone. Other institutions, such as East Sussex Record Office mentioned above, were also taking steps into computerization. To illustrate this, a table detailing the dates at which some other UK archival institutions started to use computer technology (for the production of archival finding aids or for other purposes) is included below. ${ }^{45}$

\begin{tabular}{|c|c|}
\hline Institution & Date of first operational use $e^{46}$ \\
\hline Historical Manuscripts Commission ${ }^{47}$ & $1970 / 71$ \\
\hline East Sussex Record Office ${ }^{48}$ & $1970 / 71$ \\
\hline Dyfed County Council $^{49}$ & 1977 \\
\hline House of Lords Record Office ${ }^{50}$ & 1977 \\
\hline Chester City Record Office ${ }^{51}$ & 1977 \\
\hline St John's College Cambridge ${ }^{52}$ & 1977 \\
\hline Tyne and Wear County Council ${ }^{53}$ & 1978 \\
\hline National Maritime Museum ${ }^{54}$ & $1978^{55}$ \\
\hline North West Sound Archive ${ }^{56}$ & c1979 \\
\hline British Antarctic Survey ${ }^{57}$ & $1979 / 80$ \\
\hline University of Liverpool $^{58}$ & by 1980 \\
\hline
\end{tabular}




\begin{tabular}{|c|c|}
\hline Warwick University Modern Records Centre ${ }^{59}$ & 1980 \\
\hline Durham Record Office ${ }^{60}$ & 1981 \\
\hline Greater London Record Office ${ }^{61}$ & by 1982 \\
\hline Glasgow University Archives ${ }^{62}$ & by 1982 \\
\hline $\begin{array}{l}\text { Humberside Record Office South Humberside } \\
\text { Area }^{63}\end{array}$ & by 1982 \\
\hline Hampshire Record Office ${ }^{64}$ & 1983 \\
\hline Berkshire Record Office ${ }^{65}$ & c1983 \\
\hline British Petroleum International Archives ${ }^{66}$ & c1983 \\
\hline University of Southampton $^{67}$ & 1984 \\
\hline Clwyd Record Office ${ }^{68}$ & 1984 \\
\hline West Yorkshire Archive Service ${ }^{69}$ & c1984 \\
\hline Essex Record Office ${ }^{70}$ & 1985 \\
\hline
\end{tabular}

The table shows that there was considerable activity going on outside the PRO and the PROSPEC-SA project, particularly towards the end of the 1970s and the start of the 1980s.

At that time, the desire to work together with regards to the use of computers, was as strong as it had been in the early 1970s. What was perhaps different however, was that more individual institutions and archivists (albeit still a relatively small number) were facing the immediate prospect of computerization, and consequently of, as Joan Smith, archivist at the British Antarctic Survey put it, "the first and most obvious problem [...] that data needed to be entered in clearly defined and thus manoeuverable sections and with each entry as full as possible in order to benefit from the possible multiplicity of computer generated lists and indexes. ${ }^{71}$ For these archivists there was a pressure towards strict specification, and yet, in the spirit of professional cooperation, they were also minded to generalize, to solve the aforementioned problem in a way that others could also adopt. In this position, where they came to rest was with the development of a tentative data standard, which defined the sections, or 'fields' into which data should be input in order that the computer could process it to produce a useful output or outputs.

In the late 1970s two methods of computer input were available. The first harked back to the mechanised punched card era, and involved data being key-punched onto cards or tape, usually by data preparation personnel physically removed from the office in which the data 
was initially generated. The PROSPEC-SA project worked on this model. The participating institutions completed data sheets, essentially forms, which were then edited for consistency and finally keypunched onto paper tape primarily by staff at an external company. ${ }^{72}$ This paper tape was then used as input to the computer. The experience of participants in the PROSPEC-SA project was then of an extensive and distinct process of data preparation to get that data into a form that allowed it to be input into the computer. The second method, which was starting to become more prevalent, was that of so-called 'online' working, which involved data being input directly using terminals held closer to, and in some cases, within the offices in which the data was being generated. This method was available to some, but even so, the first step in both methods tended to be the filling in of data forms. As Cook pointed out, in his 1980 book Archives and the Computer, the advantage of 'systematizing data on a special input form bearing a note of all the input formalities' was that 'Computers are particularly sensitive to incorrect input data' ${ }^{73}$ Moreover, the forms could also act as a back-up of the data, so that it was not completely lost if the still experimental computer processing did not work out as expected, or if there were lengthy delays between input into the computer and final output of a complete print-out.

In this context, the idea of focussing attention on specifying what should be recorded on these forms, what 'fields' were needed seemed a sensible one, at least to those individuals, including Joan Smith, who came together in the late 1970s as the Methods of Listing Working Party. Whilst recognising that there was a need for conventions for completing these fields, the focus remained very much more at the level of defining what fields were needed, than at that of defining the precise rules for how to enter data into them. ${ }^{74}$

One possible reason for this focus is that in the 1970s the limited (relative to today) memory and processing power of computers meant that there were often greater limitations, e.g. to the number of fields, to the number of characters that could be entered in any particular field, to the sophistication of the structures in which data was stored and so on. ${ }^{75}$ Some of these limitations had severe implications for how data was input (and hence how it would look on output), as the following extract from a report on the East Sussex Record Office's 1970/71 application shows;

there are tremendous difficulties stemming from the limitation of characters available within each section of the input form. Thus personal names have to be severely abbreviated to fit the form, so detracting from the usefulness of the personal index. ${ }^{76}$ 
Limitation in field lengths and other constraints had been quite variable, but were starting to lift in the late 1970s. Nevertheless, their existence in what was then the recent past may have mitigated against the Methods of Listing Working Party feeling able to make decisions on exact data input formats. A number of the drafts of the data standard created by the Methods of Listing Working Party start by stating the assumptions on which the standard would work, one of which was 'no restrictions on [field] length'.77

Then again, although the late 1970s/early 1980s saw a greater number of archivists implementing computerization with the requisite need that brought for strict definition, the Methods of Listing Working Party acknowledged 'that not all archivists would have immediate access to computers and that the development of a standard represented an opportunity to clarify our thinking on listing generally'. ${ }^{78}$ The majority of archivists were still not implementing computerization and the desire to include them in the conversation encouraged taking a position at a more general level. In negotiating between a pressure to specify and one to generalize, the Methods of Listing Working Party took a view of standardization/computerization that cast it very much in the guise of the broad systematization of data input.

In this endeavour, the Working Party found for a short while, common ground and support from the Museum Documentation Association (MDA). This organization had been set up in 1977 and had developed a computer system GOS, which was designed as part of an integrated Museum Documentation System which included a data standard and a series of recording forms, cards and registers. ${ }^{79}$ At some point in 1979/80 Andrew Roberts of the MDA came to a meeting of the Methods of Listing Working Party to talk about GOS. Joan Smith, a member of the Working Party was impressed by 'what the museums working in cooperation had been able to achieve' ${ }^{80}$

Smith had been appointed at BAS in 1979 and had immediately started looking at the possibility of using computers in her work. Early notes in her files from March 1979 detail a phone call with the Public Record Office discussing the available options. ${ }^{81}$ Smith experimented for a while using a system known as FAMULUS, but when she saw GOS, she arranged instead for the data already held in the FAMULUS system to be imported into GOS. By April 1981 this task had been successfully completed and Smith had made the decision to use GOS for all future descriptive work.

Although it was probably not one of the prime reasons why the Methods of Listing Working Party took the approach it did, the link with the MDA did perhaps re-enforce that approach. For example, at a Society of Archivists' In Service Training Course held in 
Cambridge from 7 to 9 July 1982, there were talks from Jennifer Stewart and Richard Light of MDA whose notes accompany some versions of the draft standard ${ }^{82}$ In June 1982, a meeting was held between the MDA and the Public Record Office, at which representatives from a number of museums, universities, galleries and archival institutions (including BAS) were present. The discussions concluded that museum archives were not a special case and that 'a documentation system suitable for museum archives should also be suitable for any archive and vice versa' ${ }^{83}$ The meeting recommended that, amongst other things, the construction of a data standard that would be compatible with the ideas of both MDA and the Methods of Listing Working Party and for MDA and the Society of Archivists to jointly seek funds for the development work. ${ }^{84}$

The collaboration with MDA appears to have reached its apogee in 1982. In the following years, attention turned to getting the archival data standard beyond the draft stage and published. A Specialist Repositories Group News bulletin from June 1983 noted that a sub-committee had been set up by the Computer Applications Committee to develop a grant application to the British Library Research and Development Fund for this purpose. ${ }^{85}$ The application was successful under the leadership of Michael Cook from the University of Liverpool and A Manual of Archival Description, which included the data standard of the Methods of Listing Working Party, was published in $1986,{ }^{86}$ again in $1989,{ }^{87}$ and most recently in $2000 .{ }^{88}$ When it became clear that the manual was nearing completion the Methods of Listing Working Party considered its work done and dissolved itself. ${ }^{89}$

From the mid-1970s to the mid-1980s, archivists in the UK were engaging with computers in ever increasing numbers. Having adopted a position that saw the computer's greatest utility in its information storage and retrieval, sorting and (re)ordering capabilities, UK archivists came to engage with it mostly in terms of data input and (to a slightly lesser degree) output. In this context, they perceived a need for standard terminologies, formats and styles of archival finding aids that was driven, in part, by the computer's requirement for rigorously and clearly defined input and, in part, by the requirement of both the computer and the archivist for a shared practice, for generalizing to the level of 'all possible systems' ${ }^{90}$ This generalization was not, for archivists, to the level of computer pioneer Alan Turing's 'universal machine', ${ }^{91}$ or to that of information theory. Rather, it was to the level of collaboration and consistency among different archival institutions, both those engaging with and those not engaging with computers, and also for a while among archives and museums, all with their own idiosyncratic practices and information needs. From this milieu standards, such as the Methods of Listing Working Party's data standard, did arise, and computers were 
used in archival practice, but a direction was also set towards what is perhaps best characterized as a process of systematization; the systematization of archivists' understanding of the activity and part of their practice they labelled archival description..$^{92}$ Further work investigating the currents of the following decade - from the mid-1980s to the mid-1990s will be needed however, before such a characterization can by entirely upheld.

\section{Conclusion}

Continuing in a tradition of looking back at the history of the archival profession's engagement with and response to computers, an original perspective has been offered through afocus on both; a) drawing a distinctive (and hence comparable) picture of archival engagement with computers in the particular context of the United Kingdom, and b) trying to unpick the relationships between computerization, standardization and systematization. The story of early archival computerization and the development of standards in the UK from the mid-1960s to roughly the mid-1980s has been set out. The work of both individual institutions - the Public Record Office, East Sussex Record Office and the British Antarctic Survey - and professional organizations - the International Council on Archives Committee on Automation, the Museum Documentation Association and the Society of Archivists' Subject Indexing Working Party, Computer Applications Committee and Methods of Listing Working Party has been highlighted.

Standardization and computerization may have initially emerged as separate threads, but these threads started to coalesce in the mid-1970s and soon became intertwined in a project of systematization that involved and evolved from the balancing of two competing pressures or forces. On the one hand, the arrival of the computer brought a need for the archival profession to engage in the rigorous analysis and strict specification demanded by the machine, but on the other it also led to a need for greater generalization. This generalization took the form (through groups such as the Computer Applications Committee and the Methods of Listing Party and through projects such as PROSPEC-SA and the development of a data standard) of a desire to work together, to build common ground and to generalize across all archival institutions and their individual practice. The project of systematization that arose from these competing pressures focussed on data input, on getting into computers the data that $\mathrm{UK}$ archivists needed to produce finding aids.

What is particularly important for the engagement of archivists with computers going forward is to acknowledge this focus and the way in which it placed them on the outside of another project of systematization going on at the same time; that of computers as 
information systems. In the UK, beyond perhaps a brief moment in the mid to late 1960s, archivists did not engage with the development of the conceptual (general) principles of the new information technology or with the ways in which meaning was being structured, represented and manipulated inside these new 'machines'. In some ways then, the story of UK archivists' engagement with computers up to the mid-1980s betrays a certain lack of engagement. In our perhaps understandable concern with thinking about the systematization of our own practice above all else, we have perhaps failed to engage with computers on their own terms; in terms of understanding how they structure, represent and create meaning. This raises an important question, but it is one that cannot be answered here in a retrospective that ends in the mid-1980s. Despite fifty years of engagement are archivists more or less engaged with computers now than they were in the 1960s? The answer to that question will shape the future of archival automation for the next fifty year and beyond.

\section{Notes}

${ }^{1}$ As well as specifically retrospective works, there are also large numbers of contemporaneous accounts and surveys of early automation. Many of these are referenced in the rest of the article. Where the accounts referenced had a very limited circulation or were not formally published, further details of where they were located by the author have been given.

${ }^{2}$ Thomas Elton Brown, "The Society of American Archivists Confronts the Computer," American Archivist 47, no. 4 (1984).

${ }^{3}$ Betsey Baldwin, "Confronting Computers: Debates about Computers at the Public Archives of Canada during the 1960s," Archivaria 62 (2006).

${ }^{4}$ Baldwin, “Confronting Computers," 178, 159.

${ }^{5}$ Greg Bak, "Media and the Messengers: Writings on Digital Archiving in Canada from the 1960s to the 1980s," Archivaria 82 (2016): 58; Greg Bak, "How Soon is Now? Writings on Digital Archiving in Canada from the 1980s to 2011," American Archivist 79, no. 2 (2016): 283.

${ }^{6}$ Bak, "How Soon is Now?," 310.

${ }^{7}$ Paul E. Ceruzzi, A History of Modern Computing (Cambridge: The MIT Press: Cambridge, Massachusetts, 2003), 143. 
${ }^{8}$ Martin Campbell-Kelly, ICL A Business and Technical History (Oxford: Clarendon Press, 1989), 245-264.

${ }^{9}$ See https://alm.axiell.com/collections-management-solutions/technology/calmarchive/ and https://alm.axiell.com/collections-management-solutions/technology/adlib/.

${ }^{10}$ Oxford English Dictionary Online Edition.

${ }^{11}$ A few examples of the literature on standardization of archival practice are as follows; Michael Cook, "Description Standards: The Struggle Towards the Light," Archivaria 34 (1992). Kent Haworth, "The Development of Descriptive Standards in Canada: A Progress Report," Archivaria 34 (1992). Hugo Stibbe, “Archival Descriptive Standards and the Archival Community: A Retrospective, 1996," Archivaria 41 (1996).

12 International Council on Archives Experts Group on Archival Description, Records in Contexts A Conceptual Model for Archival Description Consultation Draft v0.1 (Paris: ICA, 2016).

${ }^{13}$ The scheme never achieved widespread adoption and the UK archives profession continues to use a variety of subject indexing schemes. A more recent attempt at standardisation in this area is UKAT - the UK Archival Thesaurus (http://www.ukat.org.uk/). Whilst arguably garnering more traction than the 1970s attempt, it too has never fully achieved the vision of the complete standardisation of subject indexing within the archival profession in the UK.

${ }^{14}$ Society of Archivists Working Party on Subject Indexing, Subject Indexing Classification Scheme (London: Society of Archivists, 1975), v. A copy of this work can be found in the Senate House Library in London under the class mark PALAEOGRAPHY 4th Floor fol. CC25.42 [Society] (P.C.1) (7). The introduction outlines, amongst other things, the origins and history of the Working Party.

${ }^{15}$ Society of Archivists Working Party on Subject Indexing, Subject Indexing Classification Scheme, iii-iv. Hugh Taylor emigrated to Canada in 1965, where he became a prominent archival thinker. His influence on digital archiving is discussed in Bak, "Media and the Messengers".

${ }^{16}$ Society of Archivists Working Party on Subject Indexing, Subject Indexing Classification Scheme, iv.

${ }^{17}$ Philip Jones, “The Society's Chronicle; Annual Conference, Newcastle-upon-Tyne 10th and 11 th April 1964," Journal of the Society of Archivists 2, no. 10 (1964): 491. 
18 “The society's chronicle: Annual general meeting 1964," Journal of the Society of Archivists 3 no. 1 (1965): 41.

${ }^{19}$ Duncan Chalmers, "Computer Indexing in the Public Record Office," Journal of the Society of Archivists 6, no. 7 (1981).

${ }^{20}$ Minutes of the $92^{\text {nd }}$ Meeting of the Council of the Society of Archivists, 18 January 1973, item 10. Society of Archivists Papers, London Metropolitan Archives, A/SA/150.

${ }^{21}$ R.G.A. Chesterman, Transcript of a paper delivered by $M r R$ G A Chesterman, Senior Archivist (Modern Records), East Sussex Record Office to the UNESCO ICA ADP Seminar at the University of Sussex 29 August 1974. A copy of this paper can be found at the Senate House Library in London under the class mark CC25.42 (P.C.7) (2). The paper is also included in Proceedings of an International Seminar on Automatic Data Processing in Archives, eds. Lionel Bell and Michael Roper (London: HMSO, 1975).

${ }^{22}$ Michael Cook, The Management of Information from Archives (Aldershot: Gower Publishing, 1986), 159.

${ }^{23}$ Bell and Roper, Proceedings of an International Seminar.

${ }^{24}$ See Elton Brown, "The SAA Confronts the Computer" for the story of American professional response.

${ }^{25}$ For example, the planned schedule of work for the ICA Committee reported following the meeting at Liege in October 1975 included, in the short term, production of a manual on machine-readable archives and a lexicon of terms useful for archival automation, and the conducting of surveys of both archival applications and syllabi for training in archival automation. Longer term there was also talk of a new selective bibliography and a position paper on archival charges to researchers for automated processes. Not all of these aims came to fruition. "Meeting of Automation Committee." ADPA Automation - Archives Informatique 2, no. 1 (1976): 22. Two publications issued by the ICA Committee on Automation in the early 1980s are Arie Arad, M. E. Olsen and Meyer H. Fishbein, An Introduction to Archival Automation (Paris: ICA, 1981) and Meyer H Fishbein, Guidelines for Administering Machine-Reachable Archives (Paris: ICA, 1980).

${ }^{26}$ Michael Roper, "Computer Applications Committee: A consultation document," Journal of the Society of Archivists 5, no.2 (1974): 104.

${ }^{27}$ The area was not entirely ignored. The Public Record Office did devise a Provisional Guide to the Selection and Preparation for Transfer of Machine-readable Records. 
${ }^{28}$ Computer Applications Committee, Report to Council, 1975, 9. A copy of this report can be found in the Senate House Library in London under the class mark fol. CC25.42 [Society] (P.C.1) (8).

${ }^{29}$ Computer Applications Committee, Report to Council, 1975, 4.

${ }^{30}$ Chesterman, Transcript of a paper: 5.

${ }^{31}$ Computer Applications Committee, Report to Council, 1975, 4.

${ }^{32}$ Chalmers, "Computer Indexing in the Public Record Office." Classification Research Group, "The need for a faceted classification as the basis for all methods of information retrieval," Library Association Record 57, no. 7 (1955): 262-268.

${ }^{33}$ Computer Applications Committee, Report to Council, 1975, 4.

${ }^{34}$ P Simmons, Lionel Bell and Michael Roper, "PROSPEC: A Computer Application for the Public Record Office," Journal of the Society of Archivists 4, no. 5 (1972).

${ }^{35}$ A copy of the final project report by Michael Roper, Report to the British Library Research and Development Department on Project Number SI/G/217 PROSPEC-SA: Pilot Project The development of PROSPEC for wider use in providing guides to record offices Final Report for the period March 1977 to September 1978 (1978) can be found in Senate House Library in London under the class mark PALAEOGRAPHY $4^{\text {th }}$ Floor CC25.42 [Roper].

${ }^{36}$ Philip Jones, “The Society's Chronicle; Annual Conference, Newcastle-upon-Tyne 10th and 11 ${ }^{\text {th }}$ April 1964," Journal of the Society of Archivists 2, no. 10 (1964): 491.

${ }^{37}$ Philip Jones, “The Society's Chronicle; Annual Conference, Newcastle-upon-Tyne 10th and 11 ${ }^{\text {th }}$ April 1964," Journal of the Society of Archivists 2, no. 10 (1964): 491.

${ }^{38}$ Michael Roper, "Computer Applications Committee: A consultation document," Journal of the Society of Archivists 5, no.2 (1974): 104.

${ }^{39}$ Roper, "Computer Applications Committee: A consultation document," 105-106.

${ }^{40}$ Michael Roper, "PROSPEC - SA: a case study in setting up a co-operative computer project," ADPA Automation - Archives - Informatique 2, no. 2 (1977).

${ }^{41}$ Roper, "PROSPEC - SA: a case study," 10.

${ }^{42}$ Arie Arad and Lionel Bell, "Archival Description - A General System," ADPA Automation - Archives - Informatique 2, no. 3 (1978).

43 Arad and Bell, "Archival Description - A General System,” 2.

${ }^{44}$ Arad and Bell, “Archival Description - A General System,” 2. 
${ }^{45}$ The data in this table has been gathered from a number of secondary sources and should not be taken as giving a full picture. For example only four of the ten PROSPEC-SA participants appear on this list (Chester City Record Office, National Maritime Museum, University of Liverpool and West Yorkshire Archive Service) and even in these cases the date of first operational use of computers often postdates 1977/78. This is explained by the fact, that the data input and processing in the PROSPEC-SA project was provided by an external company and the archival institutions participating did not need to have, nor may they have had, their own computing provision. The PROSPEC-SA project therefore differed from the similar and earlier (from 1967) SPINDEX II project in the United States, where participants did have to have current computer capability as the model was more that they should implement the SPINDEX II programs on their local facilities, rather than using one central facility. See H Thomas Hickerson, Joan Winters and Venetia Beale, SPINDEX II at Cornell University and a Review of Archival Automation in the United States (New York: Department of Manuscripts and University Archives Cornell University Libraries, 1976), 25 26.

${ }^{46}$ Where a date of exact operation has not been given, a 'by' date is given, whereby the date given is the date of the earliest survey in which the application is reported. In these cases, the date of first operation will have been earlier.

${ }^{47}$ Lionel Bell, "Survey of Archival Data Processing Applications in Great Britain," ADPA Automation - Archives - Informatique 1, no. 3 (1975): 25. Rachel Bartle and Michael Cook, Computer applications in archives: a survey (Liverpool: Archives Unit, University of Liverpool, 1983), 42-3.

${ }^{48}$ Chesterman, Transcript of a paper, 14-15. Michael Cook, Archives and the Computer (London: Butterworths, 1980), 99-106.

${ }^{49}$ Maureen Patch and Dyfed Archives, "Records management in Dyfed." Journal of the Society of Archivists 6, no. 4 (1979). Cook, Archives and the Computer, 55-58. Bartle and Cook, Computer applications in archives, 31.

${ }^{50}$ Cook, Archives and the Computer, 93. Jennifer Hogarth and Gillian Martin, A survey of automated practice in selected record offices and other archive units 1992 (London: SLAIS, 1993), 55-57.

${ }^{51}$ Bartle and Cook, Computer applications in archives, 28-29. 
${ }^{52}$ Malcom Underwood, “A computer index for the archives of St John's College, Cambridge: A progress report," Journal of the Society of Archivists 6, no. 4 (1979). Bartle and Cook, Computer applications in archives, 47-48.

${ }^{53}$ D. J. Butler and W. H. Nicholson, "ARMS - a computer-based records management system developed by Tyne and Wear County Council," Journal of the Society of Archivists 6, no. 4 (1979). Cook, Archives and the Computer, 58-71.

${ }^{54}$ Bartle and Cook, Computer applications in archives, 41-42.

55 The date given for the National Maritime Museum is later than that of its engagement in the PROSPEC-SA project. It seems to relate to the initiation of a project to create an index to all the documents in the archive which were written, signed or annotated by Nelson, which involved the use of GOS. For a more detailed consideration of early computerisation at the National Maritime Museum, which takes into account its work more as a whole, rather than with a focus on only its manuscript and archival collections, see Jonathan Cutbill, "Documentation services at the National Maritime Museum: Project Petrel” in R.B. Light, D. A. Roberts and J. D. Stewart, Museum Documentation Systems: Developments and Applications (London: Butterworth \& Co Ltd. 1986).

${ }^{56}$ Bartle and Cook, Computer applications in archives, 44-5.

${ }^{57}$ Joan Smith, "The computer listing of archives: The British Antarctic Survey experiment," ADPA Automation - Archives - Informatique 4, nos. 1-2 (1982-1983).

${ }^{58}$ Cook, Archives and the Computer, 71-2. Bartle and Cook, Computer applications in archives, 39.

${ }^{59}$ Bartle and Cook, Computer applications in archives, 50-2.

${ }^{60}$ Bartle and Cook, Computer applications in archives, 29-31.

${ }^{61}$ Bartle and Cook, Computer applications in archives, 33-4.

${ }^{62}$ Bartle and Cook, Computer applications in archives, 32-3.

${ }^{63}$ Bartle and Cook, Computer applications in archives, 35-7.

${ }^{64}$ Society of Archivists' Newsletter No 57 (1991).

${ }^{65}$ Bartle and Cook, Computer applications in archives, 17-21.

${ }^{66}$ Anita Hollier, "Computerised finding aids at the British petroleum archive," Journal of the Society of Archivists 13, no. 2 (1992). Hogarth and Martin, A survey of automated practice,31-3. Bartle and Cook, Computer applications in archives, 24-5.

${ }^{67}$ C. M. Woolgar, "The Wellington papers database: An interim report," Journal of the Society of Archivists 9, no.1, (1988). Bartle and Cook, Computer applications in archives, 48-50. 
${ }^{68}$ C. J. Williams, "Computerisation in the Clwyd Record Office," Journal of the Society of Archivists 10, no. 2 (1989).

${ }^{69}$ Elizabeth Berry, "The West Yorkshire archive service: The development of a unified service 1974-1983 and its work to 1986," Journal of the Society of Archivists 8, no. 4 (1987).

${ }^{70}$ Hogarth and Martin, A survey of automated practice, 46-50.

${ }^{71}$ Smith, "The computer listing of archives," 78.

${ }^{72}$ One institution appears to have undertaken its own key-punching.

${ }^{73}$ Cook, Archives and the Computer, 30.

${ }^{74}$ Some drafts of the data standard produced by the Methods of Listing Working Party appear to have been accompanied by notes on the use of the data standard, which give a few formatting notes, e.g. on avoiding Roman numerals and Greek letters in reference codes, but these are not extensive. See, for example, the draft held at Senate House Library in London under the class mark PALAEOGRAPHY $4^{\text {th }}$ Floor fol. CC25.42 [Society] (P.C.1).

${ }^{75}$ The idea for the relational database is usually attributed to E.F. Codd in 1970, but it took until the early 1980s before systems based on this idea became mainstream as discussed in Kristi Berg, Tom Seymour and Richa Goel, "History of Databases," International Journal of Management \& Information Systems 17, no. 1 (2013).

${ }^{76}$ R. G. A. Chesterman, "The Operational Development of ARCAIC in the East Sussex Record Office 1970-1974" in Bell and Roper, Proceedings of an International Seminar on Automatic Data Processing in Archives, 193.

77 “The Computerised Listing of Archives" in Proceedings of a Forum held at St Bartholomew's Hospital 22-23 October 1981, Society of Archivists Specialist Repositories Group (London: Society of Archivists, 1982), 45.

${ }^{78}$ Vyse, Ruth, "The Draft Data Standard," in Proceedings of a Forum Held at Imperial College London 7 January 1983, Society of Archivists Specialist Repositories Group (London: Society of Archivists, 1983), 17.

${ }^{79}$ Maxim Surin, “Andrew Roberts on early museum computerisation in the UK". Accessed March 30, 2017, http://www.maximsurin.info/blog/andrew-roberts-on-earlymuseum-computerisation-in-the-uk/. Andrew D. Roberts and Richard B. Light, "The cooperative development of documentation in United Kingdom museums," in Museum Documentation Systems: Developments and Applications, edited by Richard B. Light, D. Andrew Roberts and Jennifer D. Stewart (London: Butterworths, 1986).

${ }^{80}$ Smith, "The computer listing of archives," 80. 
${ }^{81}$ Computerisation, 1979-81. Unpublished file held at the British Antarctic Survey, Cambridge, AD3/2/134/1 21/03(1).

${ }^{82}$ Margaret Freeth, “In-service training course, 1982," Journal of the Society of Archivists 7, no. 2 (1982): 141-142. For example, one of the draft versions of the data standard held at Senate House Library in London under the class mark PALAEOGRAPHY $4^{\text {th }}$ Floor fol. CC25.42 [Society] (P.C.1), is accompanied by notes on "Use of the draft Archival Data Standard to design record media" by Richard Light, dated 5 November 1982, and "Guidelines on completing MDS Cards" by Jennifer Stewart dated Spring 1982.

83 "Report of a Meeting between the Museum Documentation Association and The Public Record Office, June 1982" in Proceedings of a Forum held at St Bartholomew's Hospital 22-23 October 1981, Society of Archivists Specialist Repositories Group (London: Society of Archivists, 1982), 49.

84 "Report of a Meeting between the Museum Documentation Association and The Public Record Office, June 1982”, 49-50.

${ }^{85}$ Specialist Repositories Group News 2 (London: Society of Archivists, 1983).

London Metropolitan Archives, Society of Archivists Papers, A/SA/218.

${ }^{86}$ Michael Cook and Kristina Grant, A Manual of Archival Description: British Library $R \&$ \& Report 5867 (London: Society of Archivists, 1986).

${ }^{87}$ Michael Cook and Margaret Procter, A Manual of Archival Description (Aldershot: Gower, 1989).

${ }^{88}$ Margaret Procter and Michael Cook, A Manual of Archival Description (Aldershot: Gower, 2000).

${ }^{89}$ Minutes of a meeting of the Specialist Repositories Group held on 7 March 1985. Society of Archivists Papers, London Metropolitan Archives, A/SA/219.

${ }^{90}$ Arad and Bell, “Archival Description - A General System,” 2.

${ }^{91}$ Alan M Turing, "On Computable Numbers, with an application to the Entscheidungsproblem," Proceedings of the London Mathematical Society 42, no. 2 (1937): 230-265.

92 The Society of American Archivists' A Glossary of Archival and Records Terminology defines archival description as 'the process of analysing, organizing and recording details about the formal elements of a record or collection of records, such as creator, title, dates, extent and contents, to facilitate the work's identification, management, and understanding' - https://www2.archivists.org/glossary/terms/a/archival-description, accessed July 10, 2018. For further details of the origin and development of archivists' 
definition and conceptualisation of archival description, see Luciana Duranti, "Origin and Development of the Concept of Archival Description," Archivaria 35 (1993): 47-54. In this article Duranti dates the first definition of archival description to 1974 and the issue of "what the concept of archival description involves' to the 1980s. These timings would have to be considered in any attempt to trace or prove a process of or focus on archival description's systematization. 